\title{
NO EVIDENCE OF DOUBLY UNIPARENTAL INHERITANCE IN THE BROWN MUSSEL Perna perna FROM THE RFLP ANALYSES OF THE MITOCHONDRIAL 16S rDNA
}

\author{
WEBER, L.I. ${ }^{1,2}$; HILDEBRAND, C.G. ${ }^{1}$ \& CLEZAR, C. ${ }^{1}$ \\ 'Laboratorio de Genética Molecular, CTTMar, Universidade do Vale do Itajaí- UNIVALI \\ Itajaí, SC, Brazil; \\ 2Departamento de Genética, Instituto de Biologia, NUPEM/UFRJ, Universidade Federal do Rio de \\ Janeiro, Caixa Postal 119331, Macaé, RJ, Brazil. e-mail: laura.weber@ufrj.br; lauweber@gmail.com
}

\begin{abstract}
Weber, L.I.; Hildebrand, C.G. \& Clezar, C. 2009. No evidence of doubly uniparental inheritance in the brown mussel Perna perna from the RFLP analyses of the mitochondrial 16S rDNA. Braz. J. Aquat. Sci. Technol. 13(2):51-57. ISSN 1808-7035. The doubly uniparental mode of inheritance, characteristic of the Mytilidae, consists of an F-type mitochondrial lineage transmitted only through females and an M-type lineage present only in male gonads and therefore transmitted only through males. In this work, we search for evidence of two mitochondrial lineages in Perna perna by studying the same 16S rRNA region that allowed for the discovery of doubly uniparental inheritance in the Mytilus group and in one venerid clam. The region was screened for substitutions using eight restriction enzymes to analyze two kinds of tissues (somatic and gonadal) from 20 males and 20 females from the south of Brazil. A restriction map was constructed after confirming restriction sites with sequence analysis. After amplification with the same primers used in previous studies, a fragment of $517 \mathrm{bp}$ was obtained, which was $10 \mathrm{bp}$ shorter than the one from Mytilus species. No variation was found among individuals or between sexes or kinds of tissue (gonadal and somatic). The absence of variation in this region was confirmed by sequence analysis, and this result left us unable to reject the hypothesis of common maternal mitochondrial inheritance. The 16S rDNA sequence obtained for Perna perna was aligned with twenty-three representative sequences from fifteen mytilid species available in GenBank, and a neighborjoining tree was constructed. The phylogenetic analysis showed all Perna species clustered together in a single branch, which was supported $100 \%$ by bootstrap analysis and was more closely related to the branch of the Mytilus group than the other representative genera of the Mytilidae.
\end{abstract}

Keywords: Brazil, Mollusca, Mytilidae, heteroplasmy, male lineage.

\section{INTRODUCTION}

The mussels of the family Mytilidae have unique mitochondrial genome when compared with other metazoans (Hoffman et al., 1992; Boore et al., 2004; Mizi et al., 2005), as shown by studies of Mytilus edulis Linnaeus, 1758 and M. galloprovincialis (Lamarck1819). The absence of ATPase 8 and the presence of two tRNA ${ }^{\text {Met }}$ genes in the mitochondrial genome of the Mytilidae were characteristics only seen before in Nematoda (Okimoto et al., 1991). The mitochondrial genome of Mytilids shows the highest evolutionary rate within the metazoans (Hoeh et al., 1996). These authors estimated, for the genus Mytilus, about $5.23 \times 10^{-4}$ substitutions/nucleotide-site/Myr, more than twice the values estimated for Drosophila $\left(2.31 \times 10^{-4}\right.$ substitutions/nucleotide-site/Myr) and for humans (2.48 $\times 10^{-4}$ substitutions/nucleotide-site/Myr). This is attributed to the high rates of evolution of the male lineage characteristic of this group, which shows another very interesting feature of the mitochondrial genome: doubly uniparental mitochondrial inheritance (Hoeh et al., 1996).

Most metazoans inherit the mitochondrial genome in a unique matrilineal way, explained by the interruption of the passage of male mitochondria or by their destruction within the first $24 \mathrm{~h}$ after the recognition of a factor found on the male mitochondrial surface by a nuclear factor (Sutherland et al., 1998; Zouros, 2000). It is believed that this recognition system is broken in some bivalves, in which both male and female lineages have been observed, showing the exceptional doubly uniparental inheritance mode of the mitochondrial genome (DUl; Fisher \& Skibinski, 1990; Zouros et al., 1992; Zouros et al., 1994b) already observed in the Mytilidae (Fisher \& Skibinski, 1990; Zouros et al., 1992; Skibinski et al., 1994a,b; Zouros et al., 1994a,b; Rawson \& Hilbish, 1995), in the freshwater bivalves of the Unionidae family (Liu et al., 1996), and, more recently, in the Veneridae (Passamonti \& Scali, 2001). The doubly uniparental mode of inheritance is based on the 
existence of heteroplasmic males (Skibinski et al., 1994b; Zouros et al., 1994b), which have in their somatic tissues mainly the $F$ (Female) mtDNA lineage, while having in their gonads exclusively the male lineage (M) (Garrido-Ramos et al., 1998); females, meanwhile, are normally homoplasmic, with few exceptions, and have only the $\mathrm{F}$ lineage in both kinds of tissues (Ladoukakis et al., 2002; CEmietanka et al., 2004). Therefore, the F lineage is only transmitted through females, while the $M$ lineage is only transmitted through the males (Fisher \& Skibinski, 1990).

It is believed that the doubly uniparental mode of inheritance arose via the production of a new factor, which acts by interrupting the recognition of the male gamete factor localized on the external surface of the mitochondria. It is believed that this new factor may also be involved in sex determination in the Mytilidae (Zouros, 2000). When this recognition fails in the Mytilidae, the lack of recombination between lineages should lead to their divergence with time. Studies have demonstrated that the $M$ lineages in the Mytilidae evolve at higher rates than the maternal ones (Skibinski et al., 1994b; Rawson \& Hilbish, 1995; Hoeh et al., 1996; Stewart et al., 1996; Quesada et al., 1998; Skibinski et al., 1999). This fact cannot be explained by the hypothesis of evolution driven by males as in mammals (Shimmen et al., 1993) because the number of cell divisions during gametogenesis in the Mytilidae is very similar in both sexes (Rawson \& Hilbish, 1995). It is believed that selection is more relaxed in the male mitochondrial genome than in the female because the male mitochondrial genome is less functionally constricted due to its expression only in male gonads and not in somatic tissues (Skibinski et al., 1994b; Rawson \& Hilbish, 1995; Hoeh et al., 1996; Stewart et al., 1996).

Rawson \& Hilbish (1995) first found evidence of the doubly uniparental mode of inheritance of the mitochondrial genome in Mytilus edulis, $M$. galloprovincialis, and M. trossulus Gould, 1850 by studying $527 \mathrm{bp}$ of the $16 \mathrm{~S}$ rRNA gene using restriction enzymes. Nothing is known about the mode of inheritance of the mitochondrial genome in Perna perna (Linnaeus, 1758); therefore, our aim was to investigate this process using the same mitochondrial genome region of the 16S rDNA used for studying the Mytilus group.

\section{MATERIALS AND METHODS}

\section{Sampling and DNA extraction}

Forty adult individuals ( 20 females and 20 males) of $P$. perna were sampled from the locality of Penha, Santa Catarina, South Brazil. The sex was determined for all individuals, and samples from the gonads and somatic adductor muscle tissues were taken. DNA extraction from these tissues was performed according to a Proteinase-k/Phenol/Chloroform protocol (Hoelzel, 1998).

\section{RFLP pattern of the $16 S$ rDNA region}

The 16S rDNA region was amplified by the Polymerase Chain Reaction (PCR) using the primers described by Palumbi et al. (1991): AR 5'CGCCTGTTTATCAAAAACAT-3' and BR 5'CCGGTCTGAACTCAGATCACGT-3'. The $25 \mu \mathrm{L}$ PCR reaction included PCR buffer (1x), Triton-X-100 (0.1\%), dNTPs $(0.4 \mu \mathrm{M}), \mathrm{MgCl}_{2}(1 \mathrm{mM})$, primers $(0.4 \mu \mathrm{M}$ each), $1 \mathrm{U}$ of Taq DNA polymerase, and 4-7.5 $\mu \mathrm{L}$ of extracted DNA. The reaction was cycled according to the following program: 1 cycle at $94^{\circ} \mathrm{C}$ for $3 \mathrm{~min} ; 30$ cycles at $94^{\circ} \mathrm{C}$ for $20 \mathrm{~s}, 51^{\circ} \mathrm{C}$ for $20 \mathrm{~s}$, and $72^{\circ} \mathrm{C}$ for $45 \mathrm{~s}$; and a final step at $72^{\circ} \mathrm{C}$ for $3 \mathrm{~min}$. PCR products were cleaved with the following restriction enzymes: EcoR V, Hae III, Spe I, Hind III, EcoR I, Taq I, Rsa I, and Alu I. Cleavage reactions were performed in a final volume of $20 \mu \mathrm{l}$, containing $5 \mu \mathrm{L}$ of PCR product, $2 \mu \mathrm{L}$ of reaction buffer (10x), and $5 \cup(0.5 \cup$ in the case of $S p e l)$ of the restriction enzyme. Reactions were incubated overnight (after ruling out star activity) at $37^{\circ} \mathrm{C}$ and at $65^{\circ} \mathrm{C}$ for Taq $\mathrm{I}$. First, cleavage was verified for all individuals in $1.5 \%$ agarose gel electrophoresis. Then, the fragments obtained after digestion with single enzymes and different combinations of enzymes were separated by denaturing $6 \%$ polyacrylamide vertical gel electrophoresis, following the Brown (1994) protocol: $33.6 \mathrm{~g}$ urea (6M), $8 \mathrm{~mL}$ TEB 10x (Tris-Borate-EDTA buffer), $12 \mathrm{~mL} 40 \%$ Polyacrylamide (19:1), $800 \mu \mathrm{L}$ APS (ammonium persulfate, $0.1 \mathrm{~g} / 1 \mathrm{~mL}$ ), and $60 \mu \mathrm{L}$ Temed. A pre-run step was done at 75 Watts until the gel reached $70^{\circ} \mathrm{C}$. Samples were denatured for $5 \mathrm{~min}$ at $95^{\circ} \mathrm{C}$ in $1: 1$ denaturing loading buffer ( $95 \%$ deionized formamide; 0.05\% Bromophenol Blue; 0.05\% Xylene Cyanol FF; and $20 \mathrm{mM}$ EDTA, pH 8.0). Then, the samples were placed on ice and loaded into the wells of the gel. The electrophoresis was maintained at $50^{\circ} \mathrm{C}$ for $1.5 \mathrm{~h}$ at 45 Watts. DNA fragments were visualized by silver staining following the protocol of Hoelzel (1998). The restriction map was confirmed with sequence analysis, therefore some fragments were sent to Macrogen Inc, Korea for sequencing by the DNA analyzer $\mathrm{ABI} 3700$.

Perna perna sequences were compared with twenty-three representative sequences from fifteen mytilid species available in GenBank, and these sequences were used to construct a tree. Alignment of sequences was done with ClustalW (1.82) software. The evolutionary tree was constructed by neighbor-joining algorithms using Saitou \& Nei's (1987) genetic distance, and bootstrap analysis was done over 500 replications. 
MEGA 3.1 (Kumar et al. 2004) was used for this analysis.

\section{RESULTS}

The $16 \mathrm{~S}$ rDNA region in Perna perna was found to be $517 \mathrm{bp}$ in length, a measurement that was confirmed with sequence analysis (GeneBank Access Numbers: DQ923878, DQ923879, DQ923880, DQ923881, and DQ923882). The 16S rDNA fragment was cleaved by only five of the restriction enzymes used (Alu I, EcoR I, Hae III, Hind III, and Taq I). No variation was observed among individuals or between sexes or kinds of tissues (somatic and gonadal). Therefore, it was not possible to recognize different gender lineages of the mitochondrial genome in the examined $517 \mathrm{bp}$ of the $16 \mathrm{~S}$ rDNA (Figure 1). The lack of variation was confirmed by the sequence analysis. Alu I cleaved the $517 \mathrm{bp}$ product into four fragments: $252 \mathrm{bp}, 108 \mathrm{bp}, 99$ bp, and $58 \mathrm{bp}$; EcoR I cleaved it into two fragments: $166 \mathrm{bp}$ and $351 \mathrm{bp}$; Hae III also cleaved it into two fragments: $47 \mathrm{bp}$ and $470 \mathrm{bp}$; Hind III cleaved it into fragments of $250 \mathrm{bp}$ and $267 \mathrm{bp}$; and Taq I cleaved it into fragments of $424 \mathrm{bp}$ and $93 \mathrm{bp}$. The constructed restriction map of the $517 \mathrm{bp} 16 \mathrm{~S}$ rDNA region in $P$. perna showed a total of seven restriction sites, recognized by five different enzymes (Figure 2).

The 16S rDNA sequences of other Mytilidae available in GenBank allowed comparisons to only 439 bp of our sequence. The constructed tree (Figure 3) showed Perna perna from the south of Brazil clustered together with a sample of the same species from the USA. All Perna species included in the analysis were clustered together in a single branch with high certainty ( $100 \%$ bootstrap value) and were shown to be more closely related to the Mytilus group than to the other representative genera of the Mytilidae.

\section{DISCUSSION}

The universal primers AR and BR amplified a fragment of $517 \mathrm{bp}$ corresponding to part of the $16 \mathrm{~S}$ rRNA gene in Perna perna; this fragment is 10 bp shorter than the region obtained with the same primers for the Mytilus group (Rawson \& Hilbish, 1995). While analyzing this region using the restriction enzymes EcoR $V$ and Spe I, Rawson \& Hilbish (1995) found variation within species in the Mytilus group, allowing the authors to

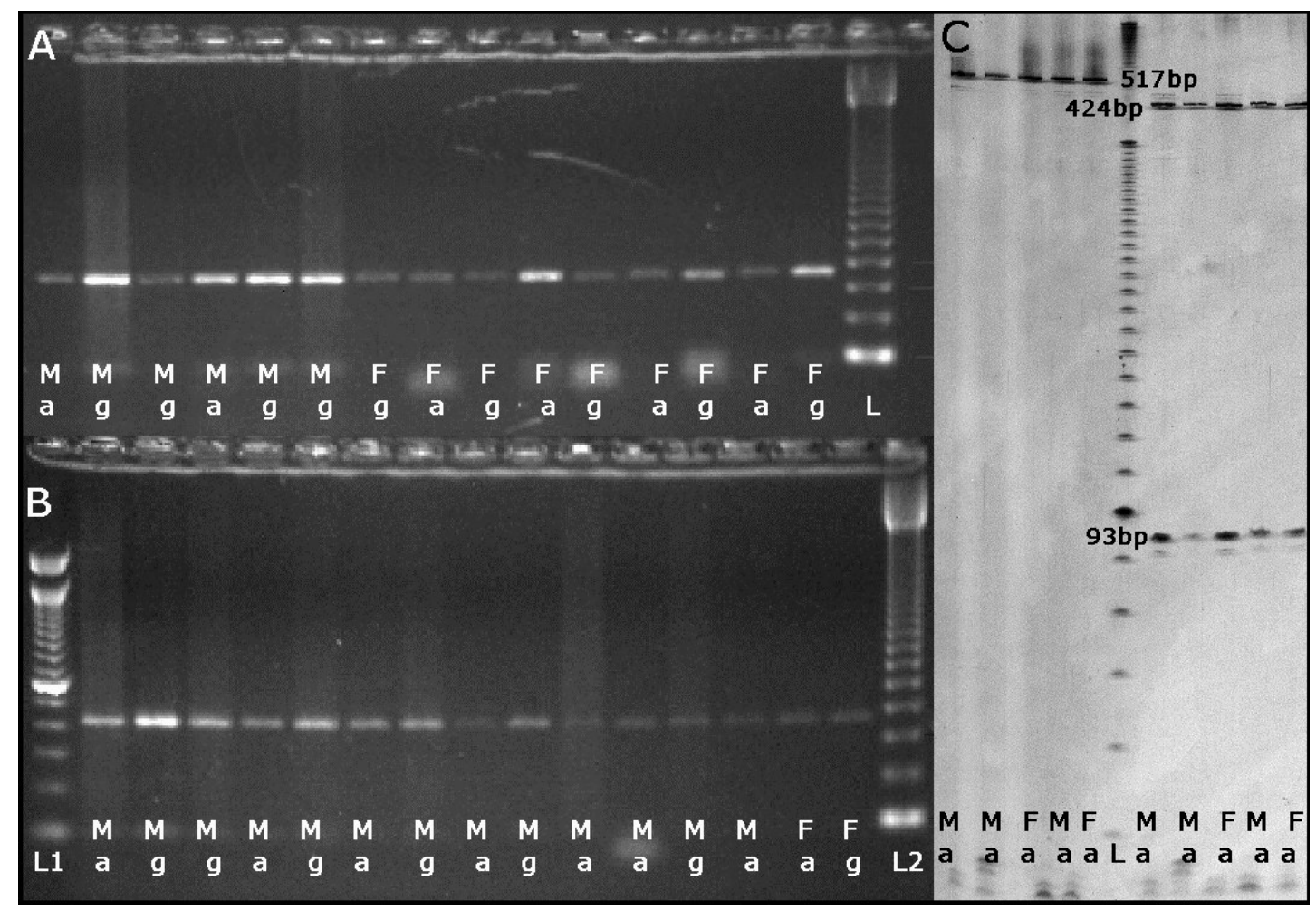

Figure 1 - DNA fragments obtained after the cleavage of the 517 bp $16 \mathrm{~S}$ rDNA fragment with Taq I restriction enzyme. A) and B) Fragments separated in 1.5\% agarose gel horizontal electrophoresis, stained with ethidium bromide and showing the 424 bp fragment; c) Fragments separated in $6 \%$ polyacrylamide gel vertical electrophoresis, stained with silver nitrate, and showing the 527 bp fragment (left), the $424 \mathrm{bp}$ and $93 \mathrm{bp}$ fragment (right); (L) $10 \mathrm{bp}$, (L1) $100 \mathrm{bp}$, and (L2) 123 bp ladders; (M) male, (F) Female, (a) adductor and (g) gonadal tissues. 
Weber et al:: No evidence of DUI in Perna perna at the 16S rDNA.

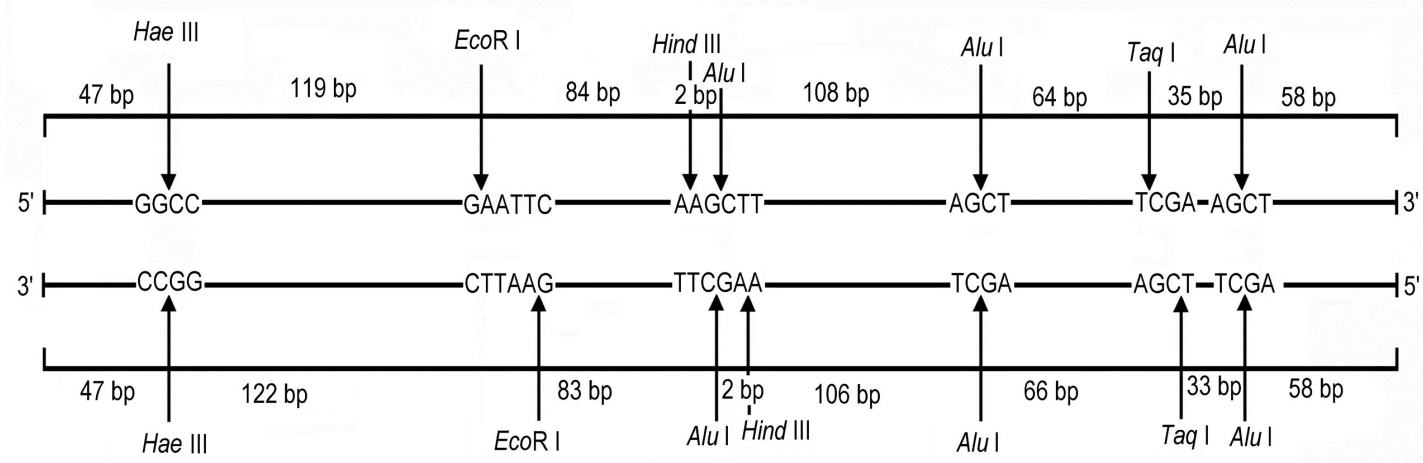

Figure 2 - Restriction map of the 517 bp 16S rDNA region from Perna perna.

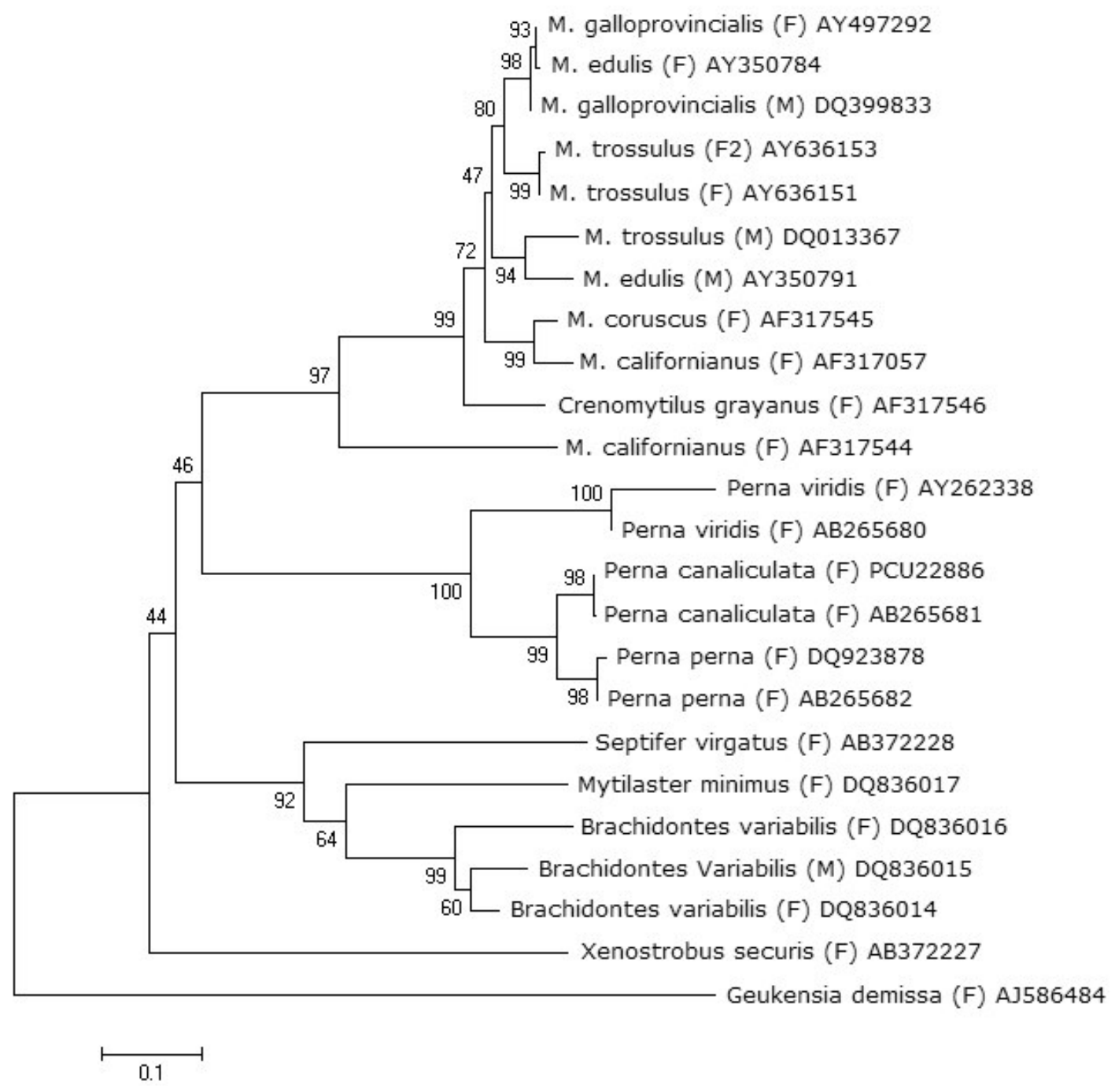

Figure 3 - Neighbor-joining tree for fifteen mytilid species, constructed from twenty-three representative sequences of the 16S rDNA region obtained from GenBank. Values at branches represent the bootstrap confidence level. 
detect the doubly uniparental inheritance in these species. Surprisingly, we were unable to detect any variation between genders and kinds of tissues; therefore, we were unable to reject the hypothesis of single maternal inheritance. This result suggests that the $16 \mathrm{~S}$ rDNA region analyzed is highly conserved in the population of Perna perna from the south of Brazil.

Studying the bivalve Tapes philippinarum (Adans \& Reeve, 1850) from the Veneridae, Passamonti \& Scali (2001) found a high divergence (75 to 78 nucleotide substitutions) between gender mitochondrial lineages at the same region studied for Perna perna. The finding that DUI is present in divergent groups of bivalve leads to the hypothesis that doubly uniparental inheritance emerged early in the bivalve and should represent an ancestral character in the group. Occasionally, the paternal route is invaded by the maternal lineage (Hoeh et al., 1997; Saavedra et al., 1997), producing a heterogeneous pool transmitted by males, so that recombination, like gene conversion, could eventually happen (Ladoukakis \& Zouros, 2001), as has been shown in M. galloprovincialis. Another event that may happen is the complete replacement of the $M$ lineage by the $F$, so that the $M$ becomes the same as the $F$, an event called the "masculinization of the F". The masculinization of the $F$ leads to the resetting of differences between both lineages to zero (Hoeh et al., 1997). Differences between the F- and M-type have already been estimated in more than $20 \%$ for the Mytilus group (Skibinski et al., 1994b).

Could Perna pernahave suffered one of the events that reset differences between lineages? Is it a species that recently invaded South America with a few founders lacking variation at this region, and their populations have not had enough time to evolve differences between gender lineages at the highly conserved 16S rDNA region? Or is the genus Perna just an exception to the doubly uniparental inheritance found in the Mytilidae?

Perna perna is the most common mussel of the south and south-east of Brazil. Although it is believed that $P$. perna was introduced into South America by ships coming from South Africa (Holland, 2001; Souza et al., 2003, 2004), this species is well-established on rocky shores, where it is predominant. No P. pernafossils were found in Brazilian prehistoric strata such as Sambaquis, where the native peral-oyster Pinctada imbricata Röding, 1798 is abundant (Souza et al., 2003). This oyster at present is almost excluded from rocky shores by P. perna (Souza et al., 2004; Weber \& Silva, 2008). Therefore, the lack of variation at this mitochondrial region might be related to a recent invasion.

Nonetheless, we cannot rule out the possibility that those primers were unable to amplify the male lineage or when isolating the male gonads, somatic tissue passed together. More extensive studies of more variable mitochondrial regions, as well as to use highly purified spermatic cells, will be necessary to clarify this point for Perna perna. Including samples from the full geographic range of the species may also be helpful to clarify this point. Non-coding regions in the mitochondrial genome also may be used, which have already been described for the Mytilidae (Hoffman et al., 1992; Cao et al., 2004; Mizi et al., 2005).

\section{ACKNOWLEDGEMENTS}

We are very grateful to the ProBIC/UNIVALI for financial support and for a grant given to C.G.H.

\section{REFERENCES}

Boore, J.L.; Medina, M. \& Rosenberg, L.A. 2004. Complete sequences of the highly rearranged mollusk mitochondrial genomes of the scaphopod Graptacme eborea and the bivalve Mytilus edulis. Mol. Biol. Evol. 21:1492-1503.

Brown, T.A. 1994. DNA sequencing: The Basics. Oxford University Press, Oxford.

Cao, L.; Kenchington, E.; Zouros, E. \& Rodakis, G.C. 2004. Evidence that the large noncoding sequence is the main control region of maternally and paternally transmitted mitochondrial genomes of the marine mussel (Mytilus spp.). Genetics. 167:835850.

Fischer, C. \& Skibinski, D.O.F. 1990. Sex-biased mitochondrial DNA heteroplasmy in the marine mussel Mytilus. Proc. R. Soc. Lond. B. 242:149156.

Garrido-Ramos, M.; Stewart, T.D.; Sutherland, W.B. \& Zouros, E. 1998. The distribution of male-transmitted and female-transmitted mitochondrial DNA types in somatic tissues of blue mussels: implications for the operation of doubly uniparental inheritance of mitochondrial DNA. Genome. 41:818-824.

Hoeh, W.R.; Stewart, D.T.; Sutherland, B.W. \& Zouros, E. 1996. Multiple origins of gender-associated mitochondrial DNA lineages in bivalves (Mollusca: Bivalvia). Evolution. 50:2276-2286.

Hoeh, W.R.; Stewart, D.T.; Saavedra, C.; Sutherland, B.W. \& Zouros, E.. 1997. Phylogenetic evidence for role-reversals of gender-associated mitochondrial DNA in Mytilus (Bivalvia: Mytilidae). Mol. Biol. Evol. 9:959-967.

Hoelzel, A.R. 1998. Molecular Genetic Analysis of Populations: a Practical Approach, 2a. Edição. Oxford University Press, New York, 445p. 
Hoffman, R.J.; Boore, J.L. \& Brown, W.M. 1992. A novel mitochondrial genome organization for the blue mussel, Mytilus edulis. Genetics. 131:397-412.

Holland, B.S. 2001. Invasion without a bottleneck: microsatellite variation in natural and invasive populations of the brown mussel Perna perna (L). Mar. Biotechnol. 3:407-415.

Kumar, S.; Tamura, K. \& Nei, M. 2004. MEGA 3: Integrated software for Molecular Evolutionary Genetic Analysis and sequence alignment. Brief. Bioinf. 5:150-163.

Ladoukakis, E.D., Saavedra, C.; Magoulas, A. \& Zouros, E. 2002. Mitochondrial DNA variation in a species with two mitochondrial genomes: the case of Mytilus galloprovincialis from the Atlantic, the Mediterranean and the Black Sea. Mol. Ecol. 11:755-769.

Ladoukakis, E.D \& Zouros, E.. 2001. Direct evidence for homologous recombination in mussel (Mytilus galloprovincialis) mitochondrial DNA. Mol. Biol. Evol. 18:1168-1175.

Liu, H.P.; Mitton, J.B. \&. Wu, S.K.. 1996. Paternal mitochondrial DNA differentiation far exceeds maternal DNA and allozyme differentiation in the freshwater mussel Anodonda grandis grandis. Evolution. 50:952-957.

Mizi, A.; Zouros, E.; Moschonas, N. \& Rodakis, G.C. 2005. The complete maternal and paternal mitochondrial genomes of the Mediterranean mussel Mytilus galloprovincialis: Implications for the doubly uniparental inheritance mode of mtDNA. Mol. Biol. Evol. 22:952-967.

Okimoto, R.; Chamberlin, H.M.; Macfarlane, J.L. \& Wolstenholme, D.R. 1991. Repeated sequence sets in mitochondrial DNA molecules of root knot nematodes (Meloidogyne): nucleotide sequences, genome location and potential for host race identification. Nucleic Acids Res. 19:1696-1626.

Palumbi, S.R.; Martin, A.P.; Romano, S.; Mcmillan, W.O.; Stice, L. \& Grabowski, G. 1991. The Simple Fool's Guide to PCR. Department of Zoology, University of Hawaii, Honolulu.

Passamonti, M. \& Scalli, V. 2001. Gender-associated mitochondrial DNA heteroplasmy in the venerid clam Tapes philippinarum (Mollusca Bivalvia). Curr. Genet. 39:117-124.

Quesada, H.; Warren, M. \& Skibinski, D.O.F. 1998. Nonneutral evolution and differential mutation rate of gender-associated mitochondrial lineages in the marine mussel Mytilus. Genetics. 149:1511-1526.

Rawson, P.D. \& Hilbish, T.J. 1995. Evolutionary relationships among the male and female mitochondrial DNA lineages in the Mytilus edulis species complex. Mol. Biol. Evol. 12:893-901.

Saavedra, C.; Reyero, M.I. \& Zouros, E. 1997. Maledependent doubly uniparental inheritance of mitochondrial DNA and female-dependent sex-ratio in the mussel Mytilus galloprovincialis. Genetics. 145:1073-1082.

Saitou, N. \& Nei, M. 1987. The neighbor-joining method: A new method for reconstructing phylogenetic trees. Mol. Biol. Evol. 4:406-425.

Shimmen, L.C.; Chang, B.H.-J. \& Li, W.-H. 1993. Male driven evolution of DNA sequences. Nature. 362:745747.

Skibinski, D.O.F.; Gallagher, C. \& Beynon, C.M. 1994a. Mitochondrial DNA inheritance. Nature. 368:817-818.

Skibinski, D.O.F.; Gallagher, C. \& Beynon, C. 1994b. Sex- limited mitochondrial DNA transmission in the marine mussel Mytilus edulis. Genetics. 138:801809.

Skibinski, D.O.F.; Gallagher, C. \& Quesada, H. 1999. On the roles of selection, mutation and drift in the evolution of mitochondrial DNA diversity in British Mytilus edulis (Mytilidae; Mollusca) populations. Biol. Jour. Linn. Soc. 68:195-213.

CEmietanka, B.; Zbawicka, M.; Wolowicz, M. \& Wenne, R. 2004. Mitochondrial DNA lineages in the European populations of mussels (Mytilus spp.). Mar. Biol. 146:79-92.

Souza, R.C.C.L.; Fernandes, F.C. \& Silva, E.P. 2003. A study on the occurrence of the brown mussel, Perna perna, on the sambaquis of the Brazilian coast. Rev. Museu Arqueol. Etnol. São Paulo 13:3-24.

Souza, R.C.C.L.; Fernandes, F.C. \& Silva, E.P. 2004. Distribuição atual do mexilhão Perna perna no mundo: Um caso recente de bioinvasão. In Silva, J.S.V. \& Souza, R.C.C.L. (eds). Água de Lastro e Bioinvasão. Interciência: Rio de Janeiro. 157-172.

Stewart, D.T.; Kenchington, E.R.; Rama, K.S. \& Zouros, E. 1996. Degree of selective constraint as an explanation of the different rates of evolution of gender-specific mitochondrial DNA lineages in the mussel Mytilus. Genetics. 143:1349-1357.

Sutherland, B.W.; Steward, D.T.; Kenchington, E.R. \& Zouros, E. 1998. The fate of paternal mitochondrial DNA in developing female mussels, Mytilus edulis: implications for the mechanism of doubly uniparental inheritance of mitochondrial DNA. Genetics. 148:341347.

Weber, L.I. \& Silva, E.P. 2008. Sistemática Molecular e Genética de Populações. In Charrid Jr, R.; Weber, L.I. \& Conceição, M.C. (eds.) O Mexilhão Perna perna (L.): Biologia, Ecologia e Aplicações. Editora Interciência, Rio de Janeiro. 121-149pp.

Zouros, E. 2000. The exceptional mitochondrial DNA system of the mussel family Mytilidae. Genes Genet. Syst. 75:313-318.

Zouros, E.; Freeman, K.R.; Ball, A.O. \& Pogson, G.H. 1992. Direct evidence for extensive paternal 
Braz. J. Aquat. Sci. Technol., 2009, 13(2):51-57.

mitochondrial DNA inheritance in the marine mussel Zouros E.; Ball, A.O.; Saavedra, C. \& Freeman, K.R. Mytilus. Nature. 359:412-414.

Zouros, E.; Ball, A.O.; Saavedra, C. \& Freeman, K.R. 1994a. Mitochondrial DNA inheritance. Nature. 368:818. 1994b. An unusual type of mitochondrial DNA inheritance in the blue mussel Mytilus. Proc. Natl. Acad. Sci. USA 91:7463-7467.

Received: March 26, 2009 Accepted: November 16, 2009 